\title{
FEATURES OF WORK CONDITIONS AND THEIR IMPACT ON HEALTH OF THE WORKERS IN LIGHT INDUSTRY
}

\section{ОСОБЛИВОСТІ УМОВ ПРАЦІ ТА ВПЛИВ ЇХ НА ЗДОРОВ'Я ПРАЦІВНИКІВ ЛЕГКОї ПРОМИСЛОВОСТІ}

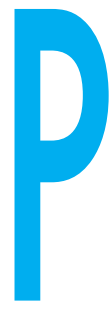

ЛОТОЦЬКА-ДУДИК У.Б., КРУПКА Н.О.

Львівський національний медичний університет ім. Данила Галицького УДК 613.6:687

Ключові слова: легка промисловість, умови праці, чинники виробничого середовища, виробничий травматизм, стан здоров'я працівників. івень соціально-економічного розвитку будь-якого суспільства визначається не тільки потужністю виробничих сил та характером виробничих відносин, технічною оснащеністю та професійною підготовленістю працівників, але й багато у чому залежить від стану їхнього здоров'я. Збереження здоров'я працівників та забезпечення безпеки на робочих місцях $€$ одним із головних завдань у законодавчій системі соціальних гарантій.

Реалізація Загальнодержавної цільової соціальної програми «Збереження і розвиток трудового потенціалу України на 2008-2017 роки» передбачає широке впровадження заходів щодо безпечних та нешкідли- вих умов праці, зниження ризику втрати здоров'я і життя працівників на виробництві. Одним із оптимальних варіантів реалізації програми $€$ посилення регуляторного впливу держави у напрямку впровадження комплексу заходів профілактики професійно-зумовленої та професійної захворюваності, зменшення факторів шкідливого впливу на організм працівників, скорочення кількості робочих місць зі шкідливими та важкими умовами праці.

На думку Н.Ф. Ізмерова (2005), попередження шкоди для здоров'я працівника порівняно $з$ матеріальними компенсаціями втрати здоров'я $€$ не просто найбільш гуманним, але й найекономічнішим шля-
ОСОБЕННОСТИ УСЛОВИЙ ТРУДА И ИХ ВЛИЯНИЕ НА ЗДОРОВЬЕ РАБОТНИКОВ ЛЕГКОЙ ПРОМЫШЛЕННОСТИ

Лотоцкая-Дудык У.Б., Крупка Н.О.

Львовский национальный медицинский университет им. Данила Галицкого

Цель работы: обобщение данных об особенностях условий труда и производственном травматизме в разных отраслях легкой промышленности, исследование их влияния на состояние здоровья и формирование профессиональнообусловленной патологии работающих

Материалы и методы исследования: результаты исследований физических и химических факторов на предприятиях легкой промышленности Львовской области, научные публикации, статистические данные.

Результаты исследования. Работники большинства профессий легкой промышленности испытывают влияние комплекса производственных факторов, среди которых доминирующее гигиеническое значение имеют повышенные уровни шума и вибрации, электромагнитное излучение, неблагоприятный микроклимат, вынужденная рабочая поза и повышенное зрительное напряжение во время выполнения технологических операций. Экспозиция канцерогенными факторами на рабочих местах составляет от 16 (производство обуви) до 33 (текстильное производство).

В структуре заболеваемости с временной потерей работоспособности преобладают болезни органов дыхания, системы кровообращения, костно-мышечной и нервной систем.

Производственно-обусловленными заболеваниями являются вертеброгенная патология, нарушение функции слухового анализатора, аллергические заболевания, в том числе бронхиальная астма, онкологические заболевания. Значительная часть факторов производственной среды в легкой промышленности проявляет свойства репротоксикантов и негативно влияет на фертильный потенциал работающих, среди которых женщины составляют от 62, 1\% (меховое производство) до 86,35\% (швейная отрасль). Отклонения репродуктивного здоровья проявляются нарушениями менструального цикла, воспалительными заболеваниями половых органов, патологией беременности и родов. Удельный вес профессиональной заболеваемости в легкой промышленности составляет 0,3-0,4 в структуре общей профессиональной заболеваемости. Наблюдается позитивная тенденция к снижению травматизма в отрасли (за 2012 г. уменьшилась в 3,8 раза в сравнении с 2008 г.), который, однако, остается самым высоким среди европейских стран. Изучение особенностей условий труда в легкой промышленности при современной организации производства и оценка состояния здоровья работников отрасли являются подпочвой для установления закономерностей формирования комплекса профессиональных факторов, причинноследственных связей между факторами производственной среды и показателями состояния здоровья рабочих и обоснования системы профилактических мероприятий по улучшению условий труда и сохранению здоровья рабочих. Ключевые слова: легкая промышленность, условия труда, факторы производственной среды, производственный травматизм, состояние здоровья рабочих.

ㄷ Лотоцька-Дудик У.Б., Крупка Н.О. СТАТТЯ, 2016. 
FEATURES OF WORK CONDITIONS AND THEIR IMPACT ON HEALTH OF THE WORKERS IN LIGHT INDUSTRY

Lototska-Dudyk U.B., Krupka N.O.

Danylo Halytskyi National Medical University, Lviv

Objective. We generalized the data on the features of work conditions and occupational traumatism in different branches of light industry and studied their impact on the state of health and the formation of the occupationally stipulated pathology in the workers.

Materials and methods. We used the results of the study of physical and chemical factors at the enterprises of light industry in the Lviv Region, scientific publications, statistical information.

Results. The workers of the majority of professions in light industry are affected a complex of production factors. Elevated levels of noise and vibration, electromagnetic radiation, unfavorable microclimate, forced working pose and increased visual tension at the performance of the technological operations have a dominant hygienic importance. A carcinogenic factor exposure at the working places makes up from 16 (shoe industry) to 33 (textile production). Diseases of respiratory, cardiovascular, nervous and musculoskeletal systems prevail in the morbidity structure with a temporal loss of capacity. Vertebral pathology, disorders of the function of acoustic analyzer, allergic diseases, including bronchial asthma, oncologic diseases are occupationally caused ones.

A considerable part of the factors of the production environment in light industry demonstrates the properties of reproductive toxicants and negatively affects the fertile potential of the workers, where the women makes up $86.35 \%$ (sewing industry) $62.1 \%$ (fur production). The deviations of reproductive health are exhibited by the disorders of menstrual cycle, genital inflammatory diseases, pathology of pregnancy and labor.

A share of occupational morbidity in light industry makes up 0.3-0.4 in the structure of general occupational morbidity. There is a positive tendency to a decline of traumatism in industry (a decrease of 3.8 times for 2012 in comparison with 2008), which, however, remains high among the European countries. Study of the features of the work conditions in light industry at modern organization of production and estimation of the state of health of the workers in industry are a basis for the establishment of the regularities of the formation of the complex of the professional factors, the cause - consequence relationships between the factors of production environment and the indices of the state of health of the workers and development of the system of prophylactic measures for the improvement of work conditions and preservation of health of the workers.

\section{Keywords: light industry, work conditions,} factors of production environment, occupational traumatism, state of health of the workers. хом розвитку суспільства, а збереження здоров'я здорових - найбільш ефективним та дешевим способом профілактики захворюваності працездатного населення.

Науково-технічний прогрес, зміни соціальної та демографічної ситуації у країні, наявність національних проектів активізували вивчення умов праці у різних галузях промисловості.

Національна легка промисловість $€$ багатогалузевим комплексом 3 виробництва товарів народного споживання, яка складається із 17 підгалузей. За даними організації економічної співпраці та розвитку (OESD), легка промисловість випереджає за обсягом машино- та автомобілебудування, оборонно-промисловий комплекс та хімічну промисловість. Виробництво продукції легкої промисловості у розвинених країнах становить 5056\% від загальної структури промисловості. В Україні легка промисловість є також однією з провідних у народному господарстві та соціально орієнтованою галуззю, в якій зайнята значна частина населення.

у літературі представлені лише окремі роботи з гігієніч- ної оцінки комплексу факторів, що діють на сучасних виробництвах легкої промисловості (Гвозденко Л.А. та співавт., Ільїнська А.В., Кузьмінов Б.П. та спіавт.), стану охорони праці у галузі (Ізовіт Т.Л.) та оцінки екологічної ситуації на цих підприємствах (Свіщев Г.А. та співавт., Гуторова Н.В.).

Вивченням умов праці та стану здоров'я працівників окремих підгалузей легкої промисловості займалися Дроботенко В.А. (віскозне виробництво), Козлова О.Л. (виробництво нетканих матеріалів), Кащеев O.В., Перхов В.І. (текстильна галузь), Галкін В.Т., Смирнова Е.В., Назаренко В.І. (швейна галузь), Черемін Р.В., Москаленко Д.М. (ткацьке виробництво), (Дементьев А.А., Морачева В.І. та співавт., Камілов Р.Ф. та співавт. (виробництво взуття), Завгородній І.В., Алімбетова Г.З., Груздьов Є.Є. (шкіряне виробництво).

Проте сучасні тенденції розвитку легкої промисловості потребують комплексного дослідження і систематизації оцінки впливу умов праці, матеріалів та технологій на здоров'я працівників та стан промислової безпеки у галузі.
Мета роботи - узагальнення даних про особливості умов праці та виробничий травматизм у різних галузях легкої промисловості, дослідження їхного впливу на стан здоров'я та формування професійно-зумовленої патології працівників.

Матеріали та методи дослідження: викопіювання протоколів досліджень фізичних факторів і хімічних чинників на підприємствах легкої промисловості Львівщини, виконаних лабораторією промислової токсикології ЛнМу ім. Данила Галицького та лабораторним центром ДСЕС України, вітчизняні і зарубіжні наукові публікації, статистичні дані.

Використано метод системного аналізу (вивчено та проаналізовано особливості умов праці у легкій промисловості, стан здоров'я та травматизму працівників галузі), а також бібліосемантичний метод (вивчено світовий досвід і вітчизняні розробки щодо визначення впливу умов та характеру праці у легкій промисловості на формування донозологічних та патологічних станів у робітників).

Результати дослідження та їх обговорення. Працівники 
більшості професій легкої промисловості у процесі виробничої діяльності зазнають впливу комплексу виробничих чинників, серед яких домінуюче гігієнічне значення мають підвищені рівні шуму і вібрації, електромагнітне випромінювання, вимушена робоча поза та підвищене зорове напруження під час виконання технологічних операцій [1].

Вагома роль відводиться також пиловому навантаженню на організм працівників. Так, за даними Галкіна В.Ж. (2005) [2], на $6,2 \%$ робочих місць швачок зареєстровано перевищення концентрації пилу, 15,2\% перевищення рівнів електростатичного поля, 59-87\% рівень освітленості суттєво нижчий від нормативної величини.

Комбінована дія шуму та вібрації $€$ одними із провідних шкідливих чинників швейного (розкрійний, швейний цехи), взуттєвого (розкрійний, вирубувальний, складальний цехи) та текстильного (ткацький цех) виробництв.

Еквівалентні рівні непостійного шуму на робочих місцях швачок становлять 91 дБА, кориговані рівні локальної вібрації - 113-115 дБ з перевищенням на частоті 125 Гц на 35 дБ [3].

Рівні шуму на робочих місцях ткаль коливаються у діапазоні 89-104 дБА. За спектром шум $€$ широкосмуговим, за часовою характеристикою - постійним. Ткацькі верстати генерують загальну технологічну вібрацію, рівні якої перевищують ГДР за осями X та Ү. Умови праці у ткацькому виробництві за рівнем шумового навантаження відповідають 3 класу 2 ступеня шкідливості та небезпечності, за рівнем вібрації класу 3.1 [4, 5].

У шкіряному виробництві на робочих місцях міздрильників, апаратників дублення, жирувальників, стругальників, тягнульників, шліфувальників, кранівників, транспортувальників реєструється перевищення еквівалентного рівня звуку на 10-25 дБА. Виробничий шум за характером спектра $є$ широкосмуговим, за часовими характеристиками непостійним, що коливається у часі. Окремі технологічні операції (міздріння, віджимання, тяжіння шкір, розведення, готування вапняного молока) супроводжуються впливом на працівників загальної технологічної або транспортно-технологічної (операція доставки матеріалів краном) вібрації робочого місця.

Ця вібрація - переважно низькочастотна з перевищенням у ряді випадків допустимих рівнів віброшвидкості та еквівалентного корегованого рівня (операція міздріння, доставки матеріалів краном). Процес обрізки та шліфування шкіри характеризується впливом на руки робітників локальної вібрації [6].

Інтенсивність шуму на окремих робочих місцях працівників взуттєвої галузі становить 76-68 дБА у заготівельних цехах, 90-92 дБА - у збиральних, 96-108 дБА - у вирубувальних. За спектральним складом шум $є$ широкосмуговим 3 переважанням допустимих рівнів за усіма октавними смугами середньогеометричних частот від 125 до 8000 Гц. За рівнем шуму робочі місця вирубки, зшивання, полірування деталей взуття характеризуються як шкідливі (клас 3.1 і 3.2) [7]

Проведені нами дослідження шумового навантаження працівників взуттєвих підприємств м. Львова показали, що рівень шуму на робочих місцях розкрійників деталей взуття становить 65,8-82 дБА, клеймування деталей $-81,5-83$ дБА, операторів швейних машин (пошиття верху та обшивання країв деталей взуття) - 67,5-73,5 дБА, затягування верху взуття - 6669,5 дБА [8].

Низка технологічних процесів виробництва взуття характеризується впливом на працівників, окрім шуму, загальної та локальної вібрації. Дія локальної вібрації супроводжується статичною напругою верхніх кінцівок (притискання і утримання заготівки). Загальний час контакту працівників з цим чинником протягом зміни сягає 85\% тривалості робочої зміни. У вирубувальному цеху рівні загальної вібрації сягають значних величин (108-112 дБ). Віброшвидкість за усіма осями (X, Y, Z) перевищує допустимі параметри [9].

Більшості підгалузей легкої промисловості притаманне насичення виробничих приміщень джерелами електромагнітних полів промислової частоти (електродвигуни обладнання, кабелі живлення, системи освітлення, електропраски тощо). За щільністю потоку електромагнітної індукції у низькочастотному діапазоні (5-2000 Гц) робочі місця у швейному, трикотажному та шкіргалантерейному виробництвах можна розділити на кілька груп: до 0,25 мкТл (апретурники, обробники ворсу, контролери продукції); 0,250,5 мкТл (настильники тканин, термообробники); 0,5-1,5 мкТл (робітники автоматизованого розкрою, закрійники, швеї на нумерації, в'язальники, оператори механічного пресу) та понад 1,5 мкТл (робітники розрізування тканин, шкіри на стрічкових пилках, швеї 3 пошиття) [10]. Залежно від розташування джерела ЕМП до зони опромінення потрапляють різні ділянки тіла робітниць. Так, за даними Охріменко П.В. [3], варіації "магнітних полів" у ділянках грудної клітки, колінного і кульшового суглобів та малого тазу становлять 0,25-0,5 мкТл і 1,5-1,8 мкТл відповідно.

Особливої уваги при вивченні впливу магнітних полів промислової частоти заслуговує проблема однонаправленої паралельної дії факторів виробничого середовища. Встановлено наявність тісного колінеарного зв'язку між максимальними рівнями магнітної індукції 50 Гц і рівнями шуму, локальної та загальної вібрації $(\ulcorner=0,9)$, що відображає технологічну єдність походження цих чинників від їхніх джерел - зростання робочої потужності електродвигуна призводить до збільшення рівня магнітного поля та шуму при його роботі. Підвищення рівнів цих чинників супроводжується зростанням напруженості праці $(\ulcorner=0,8)$ [11]. 
Мікрокліматичні параметри на робочих місцях швачок, розкрійників, термообробників, апретурників, прасувальників у швейному та трикотажному виробництвах характеризуються підвищеною температурою повітря $\left(26,5-29,0^{\circ} \mathrm{C}\right)$ та відносною вологістю (до 80\%) [10, 11]. Несприятливі мікрокліматичні умови притаманні і шкіряній галузі. Виконання відмочувально-зольних, дубильних процесів супроводжується підвищеною вологістю; сушильні, оздоблювальні процеси характеризуються підвищеними рівнями швидкості та відносної вологості повітря у холодний період року і підвищеними температурою та швидкістю руху повітря у теплий період [6].

Особливістю організації виробничого процесу більшості професій у легкій промисловості є також наявність несприятливих ергономічних чинників, монотонність та напруженість праці (тривалість зосередження - 80-90\% тривалості зміни).

За гендерним розподілом переважну кількість працівників легкої промисловості становлять жінки: у швейному виробництві - 86,35\%, текстильному - 72\%, шкіряновзуттєвому - 66,5\%, хутряному - 62,1\%. Тому здійснення моніторингу з метою оптимізації умов праці у даній галузі 3 урахуванням особливостей в окремих підгалузях на тлі погіршення демографічної ситуації в Україні $€$ вкрай важливим та актуальним.

Значна частина чинників виробничого середовища у легкій промисловості проявляє властивості репротоксикантів та негативно впливає на фертильний потенціал працівниць. Бабанов С.A. [12] наводить перелік професійних ушкоджень репродуктивної системи у жінок-працівниць легкої промисловості за умов впливу хімічних та фізичних виробничих чинників. Зокрема, наявність таких виробничих полютантів, як формальдегід, фенол, акрилонітрил, вінілхлорид, пентан, ізопентан, оксид вуглецю, оксид азоту 3 поєднанням наднормових рівнів шуму та вібрації спричиняє альгоменорею, гіперменструальний синдром, ендокринні порушення, захворювання шийки матки, загальні захворювання статевих органів, самовільні аборти, ускладнення перебігу пологів, підвищену перинатальну смертність немовлят у жінок-працівниць швейного та текстильного виробництв. Тривалий контакт 3 сірковуглецем та сірководнем у виробництві віскозного полотна призводить до порушень менструального циклу - гіпоменструального і гіперменструального синдромів у робітниць.

Шкідливі умови праці спричиняють не тільки професійну захворюваність, але й впливають на захворюваність з тимчасовою втратою працездатності (ЗТВП). Аналіз показників та структури ЗТВП на підприємствах легкої промисловості м. Києва показав, що значна питома вага належить таким нозологічним формам, як хвороби органів дихання, системи кровообігу, кістково-м'язової та нервової систем. Серед хвороб кістково-м'язової системи домінують остеохондроз та остеохондрит, нервової системи - вегетосудинна та нейроциркуляторна дистонія. Додатково реєструються хвороби репродуктивної системи [10]. Ідентичні дані отримані при поглибленому аналізі тимчасової непрацездатності робітниць швейних фабрик м. СанктПетербурга (Росія). Провідними захворюваннями у структурі ЗТВП є хвороби органів кровообігу, дихання, ендокринної і кістково-м'язової систем. За останні роки реєструється зростання в 1,5 рази гінекологічної захворюваності за рахунок збільшення частоти запальних захворювань статевих органів, клімактеричних розладів, захворювань та дисфункції молочних залоз [1]. У структурі ЗТВП працівниць швейних фабрик міст Ржев та Торжок (Росія) переважають хвороби опорнорухового апарату (1 рангове місце), органів травлення (2 рангове місце), органів зору (3 рангове місце) [2]. За віковим розподілом рівень захворюваності домінує у категоріях 30-39 років - 42\% випадків та 40-49 років - 43\%.

Поширеність захворювань серед працівників текстильних підприємств м. Москва (Росія) на 21,6\% перевищує аналогічний показник по Московській області. Хвороби органів дихання і кровообігу у структурі захворюваності текстильників складають 48\% (у Московській області і Росії відповідно 37,2\% і 33,6\%). Особливістю структури ЗТВП у зв'язку з хворобами і травмами на текстильних підприємствах Московської області є поширеність травматизму (III місце за кількістю випадків, по Росії - VII). Прихована патологія частіше виявлялася у працівників провідних виробничих цехів: прядильно-ткацького (збільшення на 51,4\%), крутильного (на 47,3\%), чесального (на 43,9\%), фарбувального (на 35,5\%) [13].

Результати порогової та надпорогової тональної аудіометрії вказують на порушення слухової функції за типом звукосприйняття, у розширеному діапазоні частот - на ушкодження периферичного та центрального відділів слухового аналізатора працівників текстильних виробництв [5].

За даними Москаленко Д.М. [14], лише близько 20\% опитаних жінок-ткаль вважають себе практично здоровими, решта відзначають порушення стану здоров'я. Встановлено пряму кореляційну залежність між стажем роботи та захворюваністю серцево-судинної системи (коефіцієнт кореляції $r=0,59$ ), функціональні порушення вегетативної нервової системи $(r=0,58)$, захворювання хребта $(r=0,51)$. У значної частини працівниць виявлені порушення репродуктивного здоров'я $(r=0,59)$, зокрема менструальної функції, перебігу вагітності, пологів та післяпологового періоду тощо. За результатами множинного кореляційного аналізу встановлено прогностичну значущість параметрів виробничого середовища щодо порушень репродуктивного здоров'я. Найбільший детермінуючий вплив мають шум $(34,8 \%)$, вібрація $(20,3 \%)$, стаж роботи (25\%). Найуразливішою з точки зору ризику порушень 
системи (гіпертонічна хвороба), органів травлення (виразкова хвороба шлунка та дванадцятипалої кишки, хронічний гастрит та хронічний холецистит), захворювань органів дихання та ендокринної системи. Виробничо-зумовленими захворюваннями для шкіряного виробництва $€$ сполучена вертеброгенна патологія та дисциркуляторна енцефалопатія, алергічні дерматити та грибкові ураження шкіри, субатрофічні фарингіти та риніти, хронічні кон'юнктивіти [6].

Деяким галузям легкої промисловості притаманна канцерогенна небезпека для здоров'я працівників [15]. За класифікацією IARC, працівники виробництва одягу на робочому місці зазнають впливу 23 канцерогенних факторів, серед яких переважають формальдегід (33,2\% працівників), поліциклічні ароматичні вуглеводні $(14,5 \%)$, тетрахлоретилен (13,3\%), природне та штучне УФВ $(9,7 \%)$, природний газ радон-222 та ДПРР (9,3\%). Особливу небезпеку становить виробництво одягу із тканин, що містять азбест (засоби захисту для пожежників тощо).

Працівники текстильного виробництва на робочому місці зазнають впливу 33 канцерогенних факторів. Домінуючими із них $є$ поліциклічні ароматичні вуглеводні (19,65\% працівників), формальдегід $(18,1 \%)$, тетрахлоретилен $(11,3 \%)$, трихлоретилен $(7,4 \%)$, сполуки хрому (VI) $(9,8 \%)$, природний газ радон-222 та ДПРР (15,2\%). Загалом текстильне виробництво належить до ІІА групи канцерогенності виробничих процесів за класифікацією IARC (без деталізації експозиції канцерогенними факторами); експонування барвниками під час фарбування тканин - до I групи канцерогенності. Доведено підвищений ризик раку яєчників працівниць текстильної промисловості при експозиції до 10 років пилу кремнію $(\mathrm{HP}=6,8 ; \mathrm{Cl}=0,6-76)$ та зворотний градієнт ризику цієї патології при виробництві бавовняної продукції (НP = 0,7; $95 \% \mathrm{Cl}=0,4-1,0)$ [16].

Працівники виробництва шкіри, хутра та виробів із них на робочому місці зазнають впливу 18 канцерогенних факторів. Домінуючими із них є: сильні неорганічні кислоти, що містять сірчану кислоту $(20,2 \%$ працівників), формальдегід $(15,2 \%)$, сполуки хрому (VI) $(15,2 \%)$, природний газ радон222 та ДПРР $(8,2 \%)$. Експонування барвниками під час фарбування шкір належить до I групи канцерогенності (без деталізації канцерогенних факторів)

Виробництво взуття також належить до канцерогенонебезпечних. Серед 16 канцерогенних факторів виробничого процесу переважають тетрахлоретилен $(21,1 \%$ працівників), трихлоретилен $(20,9 \%)$, формальдегід $(10,4 \%)$. Експонування барвниками під час фарбування взуття належить вказують на переважання патології серцево-судинної

Таблиця 1

Кількість потерпілих через нещасні випадки на виробництві у легкій промисловості за видами економічної діяльності за 2008-2012 роки

\begin{tabular}{|l|c|c|c|c|c|}
\hline \multicolumn{1}{|c|}{ Вид економічної діяльності } & 2008 р. & 2009 р. & 2010 р. & 2011 р. & 2012 p. \\
\hline Легка промисловість загалом & 113 & 72 & 70 & 41 & 30 \\
\hline Прядильне виробництво & 28 & 23 & 6 & 1 & 2 \\
\hline $\begin{array}{l}\text { Ткацьке виробництво, оздоблення тканин та текстильних } \\
\text { виробів, виробництво виробів з текстилю }\end{array}$ & 14 & 15 & 0 & 11 & 7 \\
\hline $\begin{array}{l}\text { Виробництво килимів та килимових виробів, канатів, } \\
\text { мотузок, шпагату, сіток }\end{array}$ & 1 & - & 1 & 1 & - \\
\hline $\begin{array}{l}\text { Виробництво нетканих текстильних матеріалів та виробів } \\
\text { з них, фетрових виробів, інших текстильних виробів }\end{array}$ & 14 & 6 & 2 & 11 & 8 \\
\hline Виробництво трикотажного полотна та трикотажних виробів & 3 & 1 & 1 & - & - \\
\hline Виробництво панчішно-шкарпеткових виробів & 4 & 2 & 2 & 2 & 1 \\
\hline $\begin{array}{l}\text { Виробництво одягу із шкіри, виробництво робочого одягу, } \\
\text { виробництво верхнього та спіднього одягу, виробництво } \\
\text { іншого одягу та аксесуарів }\end{array}$ & 24 & 12 & 17 & 8 & 7 \\
\hline $\begin{array}{l}\text { Вичинка та фарбування хутра й овечих шкур, виробництво } \\
\text { виробів із хутра }\end{array}$ & 1 & 1 & - & - & - \\
\hline $\begin{array}{l}\text { Виробництво шкіри, шкіряних галантерейних та дорожніх } \\
\text { виробів }\end{array}$ & 11 & 3 & 6 & 1 & 1 \\
\hline Виробництво взуття & 16 & 9 & 5 & 7 & 4 \\
\hline
\end{tabular}


до I групи канцерогенності за класифікацією IARC

Умови праці у швейній галузі впливають на процес формування здоров'я людини в онтогенезі. Встановлено тенденції щодо можливого зв'язку між захворюваністю на лімфобластну лейкемію у дітей, матері яких працювали швачками під час вагітності. За даними опитування, у несприятливих виробничих умовах сім місяців під час вагітності працювали 26 жінок (середній вік 23,4 \pm 0,9 років), які згодом народили дітей, в яких діагностовано гостру лімфобластну лейкемію. Загальна тривалість роботи швачкою до народження дитини становила від 4 місяців до 10 років (4,3 \pm 0,9 роки) [17].

Яворовський О.П. та співавтори [4] вказують, що висока частота ускладнень під час вагітності та пологів у матерівткаль сприяє порушенню стану здоров'я немовлят. Так, у 4,4\% робітниць ткацького виробництва вага немовлят була меншою, ніж 2500 г, 15,5\% дітей народилися у стані асфіксії, що практично вдвічі перевищувало ці показники у робітниць, які не контактували зі шкідливими виробничими чинниками на підприємстві.

Експозиція виробничих факторів на організм працівників легкої промисловості призводить до розвитку професійної патології. Доведеним $€$ той факт, що поєднаний вплив шкідливих виробничих чинників негативно діє на функціональний стан організму загалом за рахунок напруження фізіологічних систем, що часом сприяе розвиткові захворювань професійного характеру, навіть за малої та середньої інтенсивності їхніх параметрів. За даними Кундієва Ю.І. та співавт. [18], питома вага професійної захворюваності у легкій промисловості становить 0,3-0,4 у структурі загальної професійної захворюваності. Найвищий показник $(3,2)$ був зареєстрований 2005 року. Абсолютна кількість випадків професійної патології коливається умежах 13-30 осіб з межовим значенням 100 осіб у 2005 році.

Аналіз обставин і причин розвитку професійної патології у промисловості загалом та легкій зокрема показав, що 50$60 \%$ - це недосконалість технологій та обладнання, близько 20\% - неефективність та відсутність засобів індивідуального захисту, 4-5\% - відсутність і несправність санітарно-технічного устаткування, 3\% - неправильна організація робочих місць.

Недотримання фізіологічно раціональних режимів праці, допуск до роботи осіб з протипоказаннями, підвищена чутливість та алергізація до шкідливих факторів, несвоєчасне виявлення і пізня діагностика профзахворювань також впливають на формування професійної патології.

Умови праці у галузі взаємопов'язані зі станом промислової безпеки та охорони праці. Останнім часом спостерігається позитивна тенденція до зниження кількості потерпілих через нещасні випадки на виробництві: 2008 р. - 113 осіб, 2009 р. - 72, 2010 р. 70, 2011 p - 41, 2012 p. -30 [19] (табл. 1).

Проте за станом травматизму у галузі, у тому числі за кількістю летальних випадків, Україна суттєво вирізняється серед економічно розвинених країн Європи (табл. 2) [20].

\section{Висновки}

1. Національна легка промисловість $€$ багатогалузевим комплексом 3 виробництва товарів народного споживання, яка складається з 17 підгалузей. Це одна з провідних та соціально орієнтованих галузей, в якій зайнята значна частина населення України.

2. Працівники більшості професій легкої промисловості у процесі виробничої діяльності зазнають впливу комплексу виробничих чинників, серед яких домінуюче гігієнічне значення мають підвищені рівні шуму і вібрації, електромагнітне випромінювання, несприятливий мікроклімат, вимушена робоча поза та підвищене зорове напруження під час виконання технологічних операцій.

3. На робочих місцях працівники легкої промисловості зазнають впливу від 16 (виробництво взуття) до 33 (текстильне виробництво) канцерогенних факторів. Пріоритетними канцерогенними агентами у галузі $€$ формальдегід $(10,4-$ 33,2\% працівників), тетрахлоретилен (11,3-21,1\%), сполуки хрому (VI) (9,8-15,2\%), природний газ радон-222 та ДПРР $(8,2-15,2 \%)$.

4. У структурі захворюваності з тимчасовою втратою працездатності працівників легкої промисловості переважають такі нозологічні форми, як хвороби органів дихання, системи

Таблиця 2

Стан травматизму на підприємствах у легкій промисловості

\begin{tabular}{|l|c|c|}
\hline \multicolumn{1}{|c|}{ Країна } & $\begin{array}{c}\text { Коефіцієнт частоти } \\
\text { загального травматизму }\end{array}$ & $\begin{array}{c}\text { Коефіцієнт частоти } \\
\text { смертельного травматизму }\end{array}$ \\
\hline Великобританія & - & 0,016 \\
\hline Японія & - & 0,02 \\
\hline Швеція & - & 0,032 \\
\hline Фінляндія & - & 0,038 \\
\hline Німеччина & - & 0,08 \\
\hline Країни з ринковою економікою & 1,04 & 0,038 \\
\hline Колишні соціалістичні країни Європи & 1,65 & 0,053 \\
\hline Україна & 2,1 & 0,104 \\
\hline
\end{tabular}


комплексу професійних чинників, причинно-наслідкових зв'язків між факторами виробничого середовища і показниками стану здоров'я робітників та розроблення системи профілактичних заходів щодо поліпшення умов праці та збереження здоров'я працівників.

ЛІТЕРАТУРА

1. Смирнова Е.В.

Гигиенические особенности условий труда и их влияние на здоровье женщин, занятых в современном швейном про-

кровообігу, кістково-м'язової та нервової систем. Виробничо-зумовленими захворюваннями $€$ вертеброгенна патологія, порушення функції слухового аналізатора, алергічні захворювання, у тому числі бронхіальна астма, онкологічні захворювання.

5. Значна частина чинників виробничого середовища у легкій промисловості проявляє властивості репротоксикантів та негативно впливає на фертильний потенціал працівників. За гендерним розподілом жінки становлять від $86,35 \%$ (швейна галузь) до $62,1 \%$ (хутряне виробництво) працівників легкої промисловості. Відхилення репродуктивного здоров'я проявляються порушеннями менструального циклу, запальними захворюваннями статевих органів, патологією перебігу вагітності та пологів.

6. Поєднаний вплив шкідливих виробничих чинників негативно впливає на функціональний стан організму загалом за рахунок напруження фізіологічних систем, що у ряді випадків сприяє розвитку захворювань професійного характеру, навіть за малої та середньої інтенсивності їхніх параметрів. Питома вага професійної захворюваності у легкій промисловості становить 0,3-0,4 у структурі загальної професійної захворюваності. Останнім часом спостерігається позитивна тенденція до зниження травматизму у галузі (який у 2012 р. зменшився у 3,8 рази порівняно 32008 р.), але залишається найвищим серед європейських країн.

7. Вивчення особливостей умов праці у легкій промисловості за сучасної організації виробництва та оцінка стану здоров'я працівників галузі $€$ підґрунтям для встановлення закономірностей формування изводстве : автореф. дис. канд. мед. наук : спец 14.00.07 «Гигиена» / Е.В. Смирнова. Москва, 2007. - 20 с.

2. Галкин В.Т. Гигиеническое обоснование оптимизации питания и здоровья работниц швейного производства : автореф. дис. канд. мед. наук : спец 14.00.07 "Гигиена" / В.Т. Галкин. - Москва, 2005. - 20c.

3. Охріменко П.В. Вплив виробничих процесів на здоров'я жінок, які працюють на швейному виробництві / П.В. Охріменко // Довкілля і здоров'я. - 2009. - № 4. С. 54-57.

4. Яворовський О.П. Вплив шуму та вібрації на репродуктивне здоров'я робітниць текстильної галузі / О.П. Яворовський, С.М. Зоріна, Д.М. Москаленко // Укр. журн. 2006. - № 4 (8). - С. 30-34.

5. Клинико-аудиологическая характеристика рабочих текстильной промышленности с сенсоневральной тугоухостью на, Е.Ю. Куренева,

А.Д. Ищенко // Укр. журнал 3 проблем медицини праці. 2006. - № 3 (7). - С. 51-57.

6. Завгородній І.В. Закономірності формування комплексу професійних чинників та профілактика їх шкідливого впливу на здоров'я робітників шкіряного виробництва : автореф. дис. канд. мед. наук : спец 14.02.01 «Гігієна»/

І.В. Завгородній. - Київ, 2003. $-36 \mathrm{c}$.

7. Условия труда и здоровье работников обувного производства / В.И. Моргачева, Л.Г. Кондакова, Н.А. Дзыгал и др. // Укр. журн. з проблем медицини праці. - 2007. № 2 (10). - C. 31-40.

8. Кузьмінов Б.П. Професійні шкідливості працівників взутз проблем медицини праці. / Т.А. Шидловская, И.В Мухи- тєвих виробництв / Б.П. Кузьмінов, У.Б. Лотоцька-Дудик // Укр. журн. з проблем медицини праці. - 2015. - № 4 (5). C. 47-58.

9. Дементьев А.Л.

Особенности условий труда и заболеваемости рабочих на современном предприятии по производству обуви / А.Л. Дементьев, А.А. Ляпкало //

Гигиена и санитария. - 2001. - № 1. - C. 44-47.

10. Гігієнічна оцінка комплексу факторів, діючих на сучасних виробництвах у легкій промисловості [Електронний ресурс] / Л.А. Гвозденко, В.І. Назаренко, В.Г. Мартиросова та ін. // Актуальні питання гігієни та екологічної безпеки України : наук.-практ. конф. (до 120-річчя з дня народження О.М. Марзєєва) : тези доп. - К., 2003. - Вип. 5. - Режим доступу:

http://www.health.gov.ua/Publ/c onf.nsf/165dc8dd0ddbb56dc22 56d8f00264254/79f030beefd91 8d7c2256d96004775bf?OpenD ocument

11. Експозиція магнітного поля промислової частоти і стан здоров'я працюючих у швейному виробництві / В.І. Назаренко, О.В. Чебанова, Л.А. Гвозденко,

В.Г. Мартиросова // Укр. журн. з проблем медицини праці. 2009. - № 1 (17). -

C. 56-64.

12. Профессиональные поражения репродуктивной системы [Электронный ресурс] / С.А. Бабанов, И.А. Агаркова, И.С. Липатов, Ю.В. Тезиков // Русский мед. журн. - 2013. - № 17. Режим доступа :

http://www.rmj.ru/articles 8842.htm

13. Перхов В.И.

Исследование состояния заболеваемости и первичной медико-санитарной помощи на предприятиях текстильной промышленности: автореф. дис. канд. мед. наук : спец 14.00.33 "Общественное здоровье и здравоохранение" / В.И. Перхов. - Москва, 2009. - 21c.

14. Москаленко Д.М. Профілактика несприятливої дії шуму і вібрації на репродуктивну функцію жінок у ткацькому виробництві : автореф. дис. канд. мед. наук : спец.

14.02.01 "Гігієна" / Д.М. Москаленко. - К., 2007. - 21 с. 
15. Варивончик Д.В. Оцінка виробничої канцерогенної небезпеки у переробній галузі / Д.В. Варивончик // Укр. журн. з проблем медицини праці. - 2013. - № 2 (35). - C. 22-27.

16. Wernli K.J., Ray R.M., Li G.D. Occupational expousure and ovarian cancer in textile workers //

Epidemiology. - 2008. -

№ 2. - P. 10-14.

17. Професійна діяльність матерів дітей з гострою лімфобластною лейкемією, які проживають у Львівській області / Н.І. Кіцера, Г.Р. Акопян, Р.С. Поліщук, В.І. Назаренко // Здоровье ребенка. - 2008. № 5 (14). - С. 102-107.

18. Динаміка професійної захворюваності в Україні та досвід Інституту медицини праці НАМН України / Ю.І. Кундієв, А.М. Нагорна, М.П. Соколова, І.Г. Кононова // Укр. журн. з проблем медицини праці. - 2013. - № 4 (37). - C. 11-22.

19. Ізовіт Т.Л. Стратегічна мета уряду України - підвищення рівня промислової безпеки / Т.Л. Ізовіт // Вісник КНУТД. - 2012. - № 4. C. $116-124$.

20. Федоренко О.О. Аналіз прогнозування та попередження виробничого травматизму на підприємствах легкої промисловості / О.О. Федоренко, О.В. Мартиненко // Технології та дизайн. - 2014. - № 3 (12). - C. 1-6.

REFERENCES

1. Smirnova E.V. Gigienicheskie osobennosti uslovii truda i ikh vliianie na zdorovie zhenshchin, zaniatykh v sovremennom shveinom proizvodstve : avtoref. dis. kand. med. nauk [Hygienic Features of Work Conditions and Their Impact on Women's Health in Modern Clothing Industry: Abstract of Med. Cand. Thesis]. Moscow ; 2007 : 20 p. (in Russian).

2. Galkin V.T. Gigienicheskoe obosnovanie optimizatsii pitaniia i zdorovia rabotnits shveinogo proizvodstva : avtoref. dis. kand. med. nauk [Hygienic Substantiation of the Optimization of Nutrition and Health of the Women-Workers in Clothing Industry: Abstract of Med. Cand. Thesis]. Moscow ; 2005 : 20 p. (in Russian).

3. Okhrimenko P.V. Dovkillia i zdorovia. 2009 ; 4 : 54-57 (in
Ukrainian).

4. Yavorovsky O.P.,

Zorina S.M., Moskalenko D.M. Ukrainskyi zhurnal z problem medytsyny pratsi. 2006 ; 4 (8) : 30-34 (in Ukrainian).

5. Shidlovskaia T.A., Mukhina I.V, Kureneva E.Yu., Ishchenko A.D. Ukrainskyi zhurnal z problem meditsyny pratsi. 2006 ; 3 (7) : 51-57.

(in Russian).

6. Zavhorodnii I.V.

Zakonomirnosti formuvannia kompleksu profesiinykh chynnykiv ta profilaktyka yikh shkidlyvoho vplyvu na zdorovia robitnykiv shkirianoho vyrobnytstva : avtoref. dys. kand. med. nauk [Regularities of the Formation of the Complex of the Professional Factors and Prophylaxis of their Unhealthy Impact on the Health of the Workers in Boot and Shoe Industry : Abstract of Med.

Cand. Thesis]. Kyiv ; 2003 : 36. (in Ukrainian).

7. Morgacheva V.I., Kondakova L.G., Dzygal N.A., Dogadaeva I.I., Doshchenko V.N., Gorban L.G., Esin G.P. et al. Ukrainskyi zhurnal z problem meditsyni pratsi. 2007 ; 2 (10) : 31-40. (in Russian).

8. Kuzminov B.P., LototskaDudyk U.B. Ukrainskyi zhurnal z problem medytsyny pratsi. 2015 ; 4 (5) ; 47-58. (in Ukrainian).

9. Dementev A.L., LiapkaIo A.A. Gigiena i sanitariia. 2001 ; $1: 44-47$. (in Russian).

10. Hvozdenko L.A., Nazarenko V.I., Martyrosova V.H., Chebanova O.V., Koval L.M., Melnyk L.V. Hihiienichna otsinka kompleksu faktoriv, diiuchykh na suchasnykh vyrobnytstvakh v lehkii promyslovosti [Hygienic Assessment of the Complex of the Factors at the Modern Productions in Light Industry].

In : Aktualni pytannia hihiieny ta ekolohichnoi bezpeky Ukrainy : nauk. -prakt. konf.

[Vital Issues of Hygiene and Ecological Safety in Ukraine : Sci.-Pract. Conf.]. Kyiv ; 2003; 5. Available at :

http://www.health.gov.ua/Publ/ conf.nsf/165dc8dd0ddbb56dc2 256d8f00264254/79f030beefd 918d7c2256d96004775bf?Ope nDocument (in Ukrainian).

11. Nazarenko V.I., Chebanova O.V., Hvozdenko L.A., Martirosova V.H. Ukrainskyi zhurnal z problem medytsyny pratsi. 2009 ; 1 (17) : 56-64 (in Ukrainian).
12. Babanov S.A., Agarkova I.A., Lipatov I.S., Tezikov Yu.V. Russkii meditsinskii zhurnal. 2013 ; 17. Available at : http://www.rmj.ru/articles_8842.htm (in Russian).

13. Perkhov V.I. Issledovanie sostoianiia zabolevaemosti i pervichnoi mediko-sanitarnoi pomoshchi na predpriiatiiakh tekstilnoi promyshlennosti : avtoref. dis. kand. med. nauk [Study of the State of Morbidity and Primary Health Care at the Enterprises of Textile Industry : Abstract of Med. Cand. Thesis]. Moscow ; 2009 : 21 p. (in Russian).

14. Moskalenko D.M.

Profilaktyka nespryiatlyvoi dii shumu i vibratsii na reproduktyvnu funktsiiu zhinok u tkatskomu vyrobnytstvi : avtoref. dys. kand. med. nauk [Prophylaxis of the Hazardous Effect of Noise and Vibration on the

Reproductive Functions of the Women in Textile Industry: Abstract of Med. Cand. Thesis]. Kyiv ; $2007: 21$

(in Ukrainian).

15. Varyvonchyk D.V.

Ukrayinskyi zhurnal z problem medytsyny pratsi. $2013 ; 2(35)$ : 22-27 (in Ukrainian).

16. Wernli K.J., Ray R.M. and Li G.D. Epidemiology. 2008 ; 2 : 10-14.

17. Kitsera N.I., Akopian H.R., Polishchuk R.S., Nazarenko V.I. Zdorovie rebenka. 2008 ; 5(14) 102-107 (in Ukrainian).

18. Kundiiev Yu.I., Nahorna A.M., Sokolova M.P., Kononova $I . H$. Ukrainskyi zhurnal z problem medytsyny pratsi. 2013 ; 4 (37) : 11-22 (in Ukrainian).

19. Izovit T.L. Visnyk Kyivskoho natsionalnoho universytetu tekhnolohii ta dyzainu. 2012 ; 4 : 116-124. (in Ukrainian).

20. Fedorenko O.O., Martynenko O.V. Tekhnolohii ta dyzain. $2014: 3(12)$ : 1-6 (in Ukrainian).

Надійшла до редакції 29.01.2016 